\title{
KECEMASAN PADA IBU HAMIL DI MASA PANDEMI COVID 19 DI RSUD IBNU SUTOWO BATURAJA
}

\author{
Ayu Devita Citra Dewi, Meta Nurbaiti, Raden Surahmat, Putinah \\ STIK Bina Husada, Palembang. jalan syech Abdul Somad No.28, 22 Ilir, Kec. Bukit Kecil, Kota Palembang \\ Sumatera Selatan 30131 \\ meta.nurbaiti@gmail.com
}

\begin{abstract}
ABSTRAK
Di Indonesia, terdapat 107.000 (28,7\%) ibu hamil yang mengalami kecemasan dalam menghadapi persalinan. Kecemasan akan berdampak negatif pada ibu hamil sejak masa kehamilan hingga persalinan, seperti janin yang gelisah sehingga menghambat pertumbuhannya, melemahkan kontraksi otot rahim, dan lain-lain. Dampak tersebut dapat membahayakan ibu dan janin.Tujuan penelitian ini adalah untuk mengetahui faktor hubungan kecemasaan lbu hamil dimasa pandemi covid 19 di Poliklinik RSUD Ibnu Sutowo. Penelitian ini dilakukan menggunakan dengan pendekatan Cross Sectional dengan jumlah sampel sebanyak 37 ibu hamil dan instrumen pada penelitian ini menggunakan lembar kuesioner. Hasil analisis uji ChiSqure didapatkan ada hubungan antara umur dengan dengan kecemasandengan hasil $p$ value $0,010<\alpha(0,05)$, ada hubungan antara pendidikan dengan dengan dengan kecemasandidapatkan $p$ value $0,001<\alpha(0,05)$, ada hubungan antara pekerjaan dengan dengan kecemasan pada ibu hamil di masa pandemi covid 19 di RSUD Ibnu Sutowo Baturaja didapatkan $p$ value $0,024<a(0,05)$. Disarankan sosialisasi dan penyuluhan, pemberian leaflet tentang penyakit covid 19 dan pemeriksaan kehamilan, serta dianjurkan untuk pelaksanaan pendidikan informal untuk ibu hamil atau ibu- ibu di RSUD Ibnu Sutowo Baturaja melalui pertemuan online (daring).
\end{abstract}

Kata kunci :factor; kecemasan; ibu hamil

\section{ANXIETY IN PREGNANT MOTHERS DURING THE COVID-19 ERA AT IBNU SUTOWO HOSPITAL OFBATURAJA}

\begin{abstract}
In Indonesia, there are 107,000 (28.7\%) pregnant women who experience anxiety in facing childbirth. Anxiety will have a negative impact on pregnant women from pregnancy to delivery, such as a restless fetus that inhibits its growth, weakens uterine muscle contractions, and others. These impacts can harm the mother and fetus. The purpose of this study was to determine the relationship factors of anxiety in pregnant women during the COVID-19 pandemic at the Ibnu Sutowo Hospital of Baturaja. This research was conducted using a cross sectional approach with a sample of 37 pregnant women and the instrument in this study used a questionnaire sheet. The results of the Chi-Squre test analysis showed that there was a relationship between age and anxiety with $p$ value $0.010<(0.05)$, there was a relationship between education and anxiety, $p$ value $0.001<(0.05)$, there was a relationship between work with anxiety in pregnant women during the covid 19 pandemic at Ibnu Sutowo Hospital of Baturaja obtained p value $0.024<(0.05)$. It is recommended that socialization \& counseling, provide leaflets about Covid 19 and pregnancy checks, and it is recommended for the implementation of informal education for pregnant women or mothers at Ibnu Sutowo Hospital of Baturaja through online meetings (online).
\end{abstract}

Keywords: factors, anxiety, pregnant women.

Jurnal SMART Keperawatan is licensed under a Creative Commons Attribution-ShareAlike 4.0 International License. 


\section{LATAR BELAKANG}

Kehamilan adalah masa atau waktu sejak dinyatakan tumbuhnya janin dalam rahim, sampai 38 minggu berikutnya, yang mengalami perubahan seperti fisiologis dan psikologis (Yanti, 2019). Masa kehamilan sangat rentan dengan resiko kecacatan dan kematian yang dipengaruhi dari nutrisi, genetik hingga tingkat stresor. Tingkat stres pada masa kehamilan terutama di masa pandemi Covid 19 diketahui mengalami peningkatan yang signifikan hingga lebih $76 \%$ dan sangat beresiko terhadap janin dalam masa kehamilannya (Permatasari, 2020).

Covid-19 merupakan salah satu penyakit yang dapat meresahkan semua orang, tidak terkecuali di negara Indonesia.sangat mengganggu. Penyakit ini menyerang saluran pernafasan yang pertama kali ditemukan di Wuhan, Cina pada Bulan desember 2019 dan telah menyebar ke berbagai negara salah satunya adalah Indonesia (Mona, 2020).

Berdasarkan data Kebijakan Program Pelayanan Maternal dan Neonatal di Masa Pandemi Covid 2019 ini diketahui jumlah tingkat kehamilan mengalami peningkatan signifikat presentasinya hingga mencapai $72 \%$. Hal ini memiliki perbedaan yang sangat jauh bila dibandingkan pada tahun 2018 sebanyak $54,22 \%$ (IBI, 2020).

Kasus Corona Virus di Indonesia menurut Direktorat Kesehatan Keluarga tahun 2020 sebesar 165.887 jiwa dengan jumlah kematian yaitu 4,3\% (Astria, Y., Nurbaeti, I., \& Rosidati, 2009; Kementerian Kesehatan, 2020; Yuliani \& Aini, 2020). Kasus tersebut menyerang semua kalangan, salah satunya adalah ibu hamil (Ifa Nurhasanah, 2021). Hal ini menyebabkan ibu hamil mengalami rasa cemas bahkan sampai mengalami depresi serta dapat meningkatkan jumlah kematian. Hasil studi menunjukkan bahwa ibu hamil yang mengalami rasa cemas bahkan sampai stres diakibatkan karena berbagai macam masalah diantaranya adalah ekonomi, keluarga, pekerjaan, serta kekhawatiran terhadap kehamilan itu sendiri dan persalinan (Yuliani \& Aini, 2020).

Kecemasan menurut Mandagi merupakan keadaan yang normal terjadi dalam berbagai keadaan, seperti pertumbuhan, adanya perubahan dan pengalaman baru (Mandagi, Pali, \& Sinolungan, 2013). Kecemasan (anxiety) menurut Usman tahun 2016 merupakan perasaan takut yang tidak jelas penyebabnya dan tidak didukung oleh situasi yang ada. Selain itu menurut sodiqoh tahun 2019 kecemasan tidak dapat dihindarkan dari kehidupan sehari-hari. Kecemasan dapat dirasakan oleh setiap orang jika mengalami tekanan dan perasaan mendalam yang menyebabkan masalah psikiatrik dan dapat berkembang dalam jangka waktu lama (Angesti, 2020).

Kecemasan pada ibu hamil menurut usman tahun 2016, dapat timbul khususnya pada trimester ketiga kehamilan hingga saat persalinan, dimasa pada periode ini ibu hamil merasa cemas terhadap berbagai hal seperti normal atau tidak normal bayinya lahir, nyeri yang akan dirasakan, dan sebagainya, sehingga dengan semakin dekatnya jadwal persalinan, terutama pada kehamilan pertama, wajar jika timbul perasaan cemas atau takut karena kehamilan apalagi ditambah beban pikiran dengan adanya fenomena pandemi covid 19 (Maimunah, 2012). Menurut Stuart pada tahun 2016 terdapat beberapa faktor yang mempengaruhi kecemasan seseorang meliputi usia, jenis kelamin, pekerjaan, pengetahuan dan pendidikan (Fadli, Safruddin, Ahmad, Sumbara, \& Baharuddin, 2020).

Berdasarkan studi pendahuluan melalui wawancara dengan pendekatan pengukuran HARS pada 10 ibu hamil tanggal 24 dan 25 Maret 2021 di poliklinik RSUD Ibnu Sutowo Baturaja, didapatkan bahwa 6 (enam) ibu mengatakan cemas untuk melahirkan di rumah sakit karena masa pandemi covid 19 dan 4 (empat) ibu lainnya mengatakan cemas akan kandungan dan beresiko karena penyebaran covid 19. Pernyataan ini sejalan dengan hasil observasi pada waktu yang sama kepada $10 \mathrm{ibu}$ hamil tersebut bahwa didapatkan sebagian besar ibu hamil yang datang ke poliklinik terlihat cemas dan tidak semangat dengan kehamilannya saat berdiskusi dengan dokter. Berdasarkan fenomena diatas, penelitian ini dilakukan untuk mengetahui Kecemasan pada Ibu Hamil dimasa pandemi Covid 19 di Poliklinik Kebidanan RSUD Ibnu Sutowo. 


\section{METODE}

Penelitian kuantitatif pendekatan cross sectional dengan sampel adalah seluruh ibu hamil yang datang berkunjung memeriksakan kehamilannya di Poliklinik Kebidanan RSUD Dr. Ibnu Sutowo Baturaja, berjumlah 37 orang. Pengumpulan data dilakukan dengan metode wawancara menggunakan kuesioner dimana kuesioner di isi oleh peneliti, wawancara dengan menggunakan protokol kesehatan.Analisis data meliputi analisis univariat dan bivariat (deskritif dan analitik) dengan menggunakan uji chi-square.

\section{HASIL}

Tabel. 1 Distribusi frekuensi berdasarkan umur, pendidikan, pekerjaan dan kecemasan pada responden

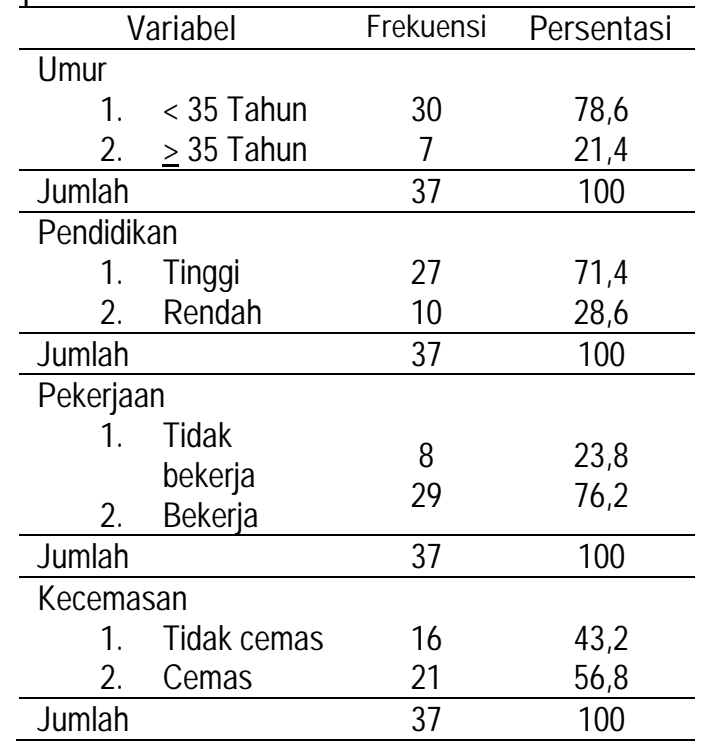

Berdasarkan hasil penelitian untuk persentase umur responden didapatkan $78,6 \%$ berumur <35 tahun (30 orang), persentase pendidikan menunjukan $71,4 \%$ berpendidikan tinggi (27 orang), untuk persentase pekerjaan didapatkan persentase $76,2 \% \%$ responden bekerja (29 orang), dan untuk kecemasan didapatkan hasil 56,8\% responden cemas (21 orang).

\section{Tabel 2. Hubungan antara Umur dengan} Kecemasan

\begin{tabular}{cccccccc}
\hline \multirow{2}{*}{ Umur } & \multicolumn{4}{c}{ Kecemasan } & \multirow{2}{*}{ Total } & \multirow{2}{*}{$\begin{array}{c}\mathrm{p} \\
\text { cemas }\end{array}$} & \multicolumn{2}{c}{ Cemas } & & & \\
\cline { 2 - 7 } & $\mathrm{n}$ & $\%$ & $\mathrm{n}$ & $\%$ & $\mathrm{n}$ & $\%$ & \\
\hline$<35$ tahun & 14 & 30,3 & 16 & 69,7 & 30 & 100,0 & \\
$\geq 35$ tahun & 2 & 22,2 & 5 & 77,8 & 7 & 100,0 & 0,010 \\
\hline Jumlah & 16 & & 21 & & 37 & & \\
\hline
\end{tabular}

Pada tabel 1 diatas didapatkan responden yang usia < 35 tahun yang tidak cemas sebanyak 14 responden (30,3\%) dari 30 responden, sedangkan responden yang usia $\geq 35$ tahun yang cemas sebanyak 5 responden $(77,8 \%)$ dari 7 responden. Berdasarkan hasil uji Chi Square didapatkan $p$ value $0,010<\alpha(0,05)$ menunjukkan bahwa ada hubungan antara umur dengan dengan kecemasan pada ibu hamil di masa pandemi covid 19 di RSUD Ibnu Sutowo Baturaja.

Tabel 2. Hubungan antara Pendidikan dengan Kecemasan

\begin{tabular}{cccccccc}
\hline & \multicolumn{4}{c}{ Kepatuhan } & & \multirow{2}{*}{ Total } & $\begin{array}{c}\mathrm{p} \\
\text { Value }\end{array}$ \\
\cline { 2 - 6 } Pendidikan & \multicolumn{2}{c}{$\begin{array}{c}\text { Tidak } \\
\text { cemas }\end{array}$} & \multicolumn{2}{c}{ Cemas } & & & \\
\cline { 2 - 6 } & $\mathrm{N}$ & $\%$ & $\mathrm{n}$ & $\%$ & $\mathrm{n}$ & $\%$ & \\
\hline Tinggi & 12 & 44,4 & 15 & 55,6 & 27 & 100,0 & \\
Rendah & 4 & 40,0 & 6 & 60,0 & 10 & 100,0 & 0,001 \\
\hline Jumlah & 16 & & 21 & & 37 & & \\
\hline
\end{tabular}

Pada tabel 2 diatas didapatkan responden yang berpendidikan tinggi dengan tidak cemas yaitu sebanyak 12 responden $(44,4 \%)$ dari 27 responden, sedangkan responden yang berpendidikan rendah yang cemas yaitu sebanyak 6 responden $(60,0 \%)$ dari 10 responden. Berdasarkan hasil uji Chi Square didapatkan $p$ value $0,001<\alpha(0,05)$ menunjukkan bahwa ada hubungan antara pendidikan dengan dengan dengan kecemasan pada ibu hamil di masa pandemi covid 19 di RSUD Ibnu Sutowo Baturaja.

Tabel 3.Hubungan antara Pekerjaan dengan Kecemasan

\begin{tabular}{|c|c|c|c|c|c|c|c|}
\hline \multirow{3}{*}{ Pekerjaan } & \multicolumn{4}{|c|}{ Kecemasan } & \multirow{2}{*}{\multicolumn{2}{|c|}{ Total }} & \multirow{3}{*}{$\begin{array}{c}\mathrm{p} \\
\text { Value }\end{array}$} \\
\hline & \multicolumn{2}{|c|}{$\begin{array}{l}\text { Tidak } \\
\text { cemas }\end{array}$} & \multicolumn{2}{|c|}{ Cemas } & & & \\
\hline & $\mathrm{N}$ & $\%$ & $n$ & $\%$ & $\mathrm{n}$ & $\%$ & \\
\hline $\begin{array}{c}\text { Tidak } \\
\text { bekerja }\end{array}$ & 7 & 90,0 & 1 & 10,0 & 8 & 100,0 & מת 0 ( \\
\hline Bekerja & 9 & 31,0 & 20 & 69,0 & 29 & 100,0 & $0,0<4$ \\
\hline Jumlah & 16 & & 21 & & 37 & & \\
\hline
\end{tabular}

Pada tabel 3 diatas didapatkan responden tidak bekerja yang tidak cemas sebanyak responden $(90,0 \%)$ dari 8 responden, sedangkan responden bekerja yang cemas sebanyak 20 responden ( $69,0 \%$ ) dari 29 responden.Berdasarkan hasil uji Chi Square didapatkan $p$ value $0,024<\alpha(0,05)$ menunjukkan bahwa ada hubungan antara 
pekerjaan dengan dengan kecemasan pada ibu hamil di masa pandemi covid 19 di RSUD Ibnu Sutowo Baturaja.

\section{PEMBAHASAN}

\section{Hubungan antara umur dengan kecemasan}

Umur menunjukan ukuran waktu pertumbuhan dan perkembangan seorang individu. Umur berkorelasi dengan pengalaman, pengalaman berkorelasi dengan pengetahuan, pemahaman dan pandangan terhadap suatu penyakit atau kejadian sehingga akan membentuk persepsi dan sikap. Kematangan dalam proses berpikir pada individu yang berumur dewasa lebih memungkinkannya untuk menggunakan mekanisme koping yang baik dibandingkan kelompok umur anak-anak, ditemukan sebagian besar kelompok umur anak yang mengalami insiden fraktur cenderung lebih mengalami respon cemas yang berat dibandingkan kelompok umur dewasa.

Bertambahnya umur seseorang akan mengalami perubahan aspek fisik dan psikologis (mental). Secara garis besar, pertumbuhan fisik terdiri atas empat kategori perubahan yaitu perubahan ukuran, perubahan proporsi, hilangnya ciri-ciri lama, dan timbulnya ciri-ciri baru. Perubahan ini terjadi karena pematangan fungsi organ. Pada aspek psikologis atau mental, taraf berfikir seseorang menjadi semakin matang dan dewasa (Iqbal, 2012).

Hasil penelitian ini yang menunjukkan adanya hubungan variabel umur dan kecemasan, hasil penelitian ini sejalan dengan penelitian Etri (2020) bahwa pengetahuan dan usia memiliki hubungan dengan kecemasan, akan tetapi tidak dengan pekerjaan dimana nilai $p$ value adalah 0,114 (Y. Etri; Irman Veolina; Harmawati, 2020).

Berdasarkan hasil penelitian dan teori yang ada, peneliti berpendapat bahwa ada hubungan bermakna antara umur dan kecemasan. Karena umur ibu sangat menentukan kesehatan maternal karena berkaitan dengan kondisi anatomi dan fisiologi selama kehamilan, persalinan, dan nifas. Selain dari anatomi secara psikologis pada umur dewasa seseorang telah mampu untuk memecahkan masalah-masalah yang dihadapi dengan tenang secara emosional, terutama dalam menghadapi kehamilan, persalinan, nifas.

\section{Hubungan antara Pendidikan dengan Kecemasan}

Responden yang berpendidikan tinggi lebih mampu menggunakan pemahaman mereka dalam merespon suatu kejadian secara adaptif dibandingkan kelompok responden yang berpendidikan rendah (Rozikhan Rozikhan, 2021). Kondisi ini menunjukan respon cemas berat cenderung dapat kita temukan pada responden yang berpendidikan rendah karena rendahnya pemahanan mereka terhadap suatu kejadian sehingga membentuk persepsi yang menakutkan bagi mereka dalam merespon (Aslinda Hafid, 2021)

Pendidikan berarti bimbingan yang diberikan seseorang kepada orang lain agar dapat memahami sesuatu hal. Tidak dapat dipungkiri bahwa semakin tinggi pendidikan seseorang, semakin mudah pula mereka menerima informasi, dan pada akhirnya pengetahuan yang dimilikinya akan semakin banyak. Sebaliknya, jika seseorang memiliki tingkat pendidikan yang rendah, maka akan menghambat perkembangan sikap orang tersebut terhadap penerimaan informasi dan nilainilai yang baru diperkenalkan (Iqbal, 2012). Tingkat pendidikan masyarakatyang rendah sering kali menjadi tuduhan utama sebagai penyebab sehingga ibu-ibu tidak mempunyai kesempatan untuk mendapatkan informasi yang baik (Dewi, 2018).

Hasil penelitian ini yang menunjukkan adanya hubungan variabel pendidikan dan kecemasan sama dengan pernyataan oleh Handayani bahwa pengetahuan, pendidikan, usia memiliki hubungan yang signifikan terhadap tingkat kecemasan dengan nilai $p$ value ketiganya $<0,05$ (Handayani, 2016)(Handayani, 2016). Selain itu juga tingkat kecemasan dapat dipengaruhi oleh pemberian pendidikan dengan cara mengajarkan pasien tentang tehnik relaksasi (Anggara \& Nurbaiti, 2021).

Berdasarkan hasil penelitian dan teori yang ada, peneliti berpendapat bahwa ada hubungan antara pendidikan dengan kecemasan ibu hamil. Karena tingkat pendidikan ibu yang rendah mengakibatkan kurangnya pengetahuan ibu dalam menghadapi masalah, terutama dalam mengambil tindakan dalam menjaga kesehatan kehamilannya terutama dalam kondisi pandemi covid 19 sekarang. Sedangkan ibu-ibu yang mempunyai tingkat pendidikan yang lebih tinggi, 
umumnya terbuka menerima perubahan atau halhal baru guna pemeliharaan kesehatanya. Misalnya dengan menggunakan masker, menjaga jarak dan selalu mencuci tangan.

\section{Hubungan antara Pekerjaan dengan Kecemasan}

Kecemasan orang yang bekerja dan tidak bekerja tentu berbeda. Individu yang tidak bekerja cenderung memiliki beban pikiran yang lebih ringan dari pada yang bekerja lain halnya dengan orang yang bekerja, kecemasan cenderung diakibatkan oleh beban pekerjaan dan beban urusan rumah tangga (Nekada, Deni, \& Krisnanto3, 2020). Orang yang bekerja cenderung mengalami stres akibat beban pekerjaan yang dimilikinya. Mayoritas ibu yang bekerja mengalami kecemasan (Hendriani, D., Widyastuti, H. P., Putri, R. A., \& Puspitaningsih, 2021). Pekerjaan adalah kegiatan yang harus dilakukan terutama untuk menunjang kehidupannya dan keluarga. Pekerjaan bukan sumber kesenangan, tetapi lebih banyak merupakan cara mencari nafkah yang membosankan, berulang dan banyak tantangan. Lingkungan pekerjaan dapat membuat seseorang memperoleh pengalaman dan pengetahuan, baik secara langsung maupun tidak langsung (Iqbal, 2012).

Hasil penelitian ini menunjukkan adanya hubungan antara variabel pekerjaan dan kecemasan sama dengan hasil penelitian yang dilakukan Suyani didapat hasil hubungan antara status pekerjaan ibu dengan kecemasan pada ibu hamil trimester III dengan $p$ value 0.01 (Suyani, 2020).

Berdasarkan hasil penelitian dan teori yang ada, peneliti berpendapat bahwa ada hubungan bermakna antara pekerjaan dan kecemasan ibu hamil dalam menghadapi kehamilan dan penyakit covid 19. Karena bagi ibu-ibu yang bekerja mereka harus sering keluar rumah, sering bertemu dengan teman kerja ataupun konsumen dan ditambah dengan beban kerja.

\section{KESIMPULAN DAN SARAN}

Hasil analisis uji Chi- Squre didapatkan ada hubungan antara umur dengan dengan kecemasan dengan hasil $p$ value $0,010<\alpha(0,05)$, ada hubungan antara pendidikan dengan dengan dengan kecemasan didapatkan $p$ value $0,001<\alpha$
$(0,05)$, ada hubungan antara pekerjaan dengan dengan kecemasan pada ibu hamil di masa pandemi covid 19 di RSUD Ibnu Sutowo Baturaja didapatkan $p$ value $0,024<\alpha(0,05)$.

Kelas ibu hamil untuk diadakan lebih sering berupa sosialisasi dan penyuluhan, pemberian leaflet tentang penyakit covid 19 dan pemeriksaan kehamilan, serta dianjurkan umtuk pelaksanaan pendidikan informal untuk ibu hamil atau ibu- ibu di RSUD Ibnu Sutowo Baturaja melalui pertemuan online (daring) yang dapat dijadwalkan sesuai dengan aturan yang berlaku di rumah sakit.

\section{REFERENS}

Angesti, E. P. W. (2020). Hubungan Tingkat Kecemasan Dan Pengetahuan lbu Hamil Trimester 3 Dengan Kesiapan Menghadapi Persalinan Di Masa Pandemi Covid-19 Di Puskesmas Benowo Dan Tenggilis.

Anggara, A., \& Nurbaiti, M. (2021). PERSALINAN EFFECT OF GIVING BREATH. Prosiding Seminar Nasional Stikes Syedza Saintika, 1(1), 264-270.

Aslinda Hafid, H. H. (2021). Hubungan Kejadian Pandemi Covid 19 Dengan Kecemasan Ibu Hamil Trimester Tiga. Jurnal Keperawatan Muhammadiyah, 6(2), 151-155.

Astria, Y., Nurbaeti, I., \& Rosidati, C. (2009). (2009). Hubungan Karakteristik Ibu Hamil Dengan Kecemasan Dalam Menghadapi Persalinan, 10(19)

Dewi, A. (2018). Hubungan Pendidikandan Dukungan Tenaga Kesehatan dengan ASI Eksklusifdi Puskesmas Merdeka Palembang Tahun 2018. Masker Medika, 6(2), 389-395.

Fadli, F., Safruddin, S., Ahmad, A. S., Sumbara, S., \& Baharuddin, R. (2020). Faktor yang Mempengaruhi Kecemasan pada Tenaga Kesehatan Dalam Upaya Pencegahan Covid-19. Jurnal Pendidikan Keperawatan Indonesia, 6(1), 57-65. https://doi.org/10.17509/jpki.v6i1.24546

Handayani, R. (2016). Faktor-Faktor Yang Berhubungan Dengan Tingkat Kecemasan Menjelang Persalinan Pada Ibu Primigravida Trimester III di Wilayah Kerja Puskesmas Lubuk Buaya Padang Tahun 2012. Jurnal Ners Keperawatan, 11(1).

Hendriani, D., Widyastuti, H. P., Putri, R. A., \& Puspitaningsih, R. (2021). Peran Suami Dalam Gangguan Kecemasan Dan Stress Pada Ibu Hamil Selama Pandemi Covid-19. Mahakam 
Midwifery Journal, 6(1), 28-36.

IBI. (2020). Situasi Pelayanan Kebidanan pada Masa Pandemi COVID-19 dan Memasuki Era New Normal, Webinar in 2020. Ibi.or.ld, 1-32. Retrieved from https://www.ibi.or.id/id/article_view/A202006110 01/unduh-materi-webinar-ibi-usaid-jalin-seri-510-juni-2020.html

Ifa Nurhasanah. (2021). Faktoryang Mempengaruhi Kecemasan pada lbu Hamil saat Pandemi COVID-19: Literatur Review. Jurnal Bidan Komunitas, 4(1).

Iqbal, M. W. (2012). IImu kesehatan masyarakat konsep dan aplikasi dalam kebidanan. Jakarta: Salemba Medika.

Kementerian Kesehatan, R. (2020). Pedoman Bagi Ibu Hamil, Bersalin, Nifas, dan Bayi Baru Lahir Di Era Pandemi COVID-19.

Maimunah, S. (2012). Kecemasan ibu hamil menjelang persalinan pertama. Jurnal Humanity, 5(1).

Mandagi, D. V. V., Pali, C., \& Sinolungan, J. S. V. (2013). Perbedaan Tingkat Kecemasan Pada Primigravida Dan Multigravida Di Rsia Kasih Ibu Manado. Jurnal E-Biomedik, 1(1), 197-201. https://doi.org/10.35790/ebm.1.1.2013.1617

Mona, N. (2020). Konsep Isolasi Dalam Jaringan Sosial Untuk Meminimalisasi Efek Contagious (Kasus Penyebaran Virus Corona Di Indonesia). Jurnal Sosial Humaniora Terapan, 2(2), 117125. https://doi.org/10.7454/jsht.v2i2.86

Nekada, C. D. Y., Deni, P., \& Krisnanto3. (2020). Tetap Bekerja Di Tengah Kecemasan Terhadap Pandemi Covid-19. Prosiding Seminar Nasional,
2(1), 158-165. Retrieved from file:///D:/SKRIPSI 2021/JURNAL/TETAP BEKERJA DI TENGAH KECEMASAN TERHADAP.pdf

Permatasari, A. S. (2020). Self-Hypnosis Terhadap Tingkat Kecemasan Ibu Hamil Dalam Persiapan Menghadapi Persalinan Di Masa Pandemic. Public Knowladge Project, 58.

Rozikhan Rozikhan, T. S. (2021). Perbedaan Tingkat Kecemasan Ibu Hamil Primigravida Dengan Multigravidadi Era Pandemi Covid-19 di Wilayah Kabupaten Kendal. Midwifery Care Jurnal, 2(1), 15-20.

Suyani. (2020). Hubungan Tingkat Pendidikan Dan Status Pekerjaan Dengan Kecemasan Pada Ibu Hamil Trimester III. JKM Jurnal Kesehatan Masyarakat STIKES Cendekia Utama Kudus, 8(1), 19-28.

Y. Etri; Irman Veolina; Harmawati. (2020). Optimalisasi Kesehatan Ibu Hamil Selama. Jurnal Abdimas Saintika, 1(1), 1-8. Retrieved from http://jurnal.syedzasaintika.ac.id/index.php/abdi mas/article/view/853

Yuliani, D. R., \& Aini, F. N. (2020). Kecemasan Ibu Hamil Dan Ibu Nifas Pada Masa Pandemi Covid19 Di Kecamatan Baturraden. Jurnal Sains Kebidanan, 2(2), 11-14. https://doi.org/10.31983/jsk.v2i2.6487 